貧弱であり再現性が困難である.

32席福神らは固定具を自ら作製し適格な固定と高い再 現性を得, 診断能の高い画像を得るととに成功してい る.

36席田中らは第 1 世代の装置を使用し, 前額, 知状断 層画像をソフトの改良とスライス厚を変化さし, 再構成 画像処理をおこない得ている．5 mm 厚スキャンであれ ば診断の一助となるとしている.

CT, 断層とも診断能の高い画像を得るため多量なX線 被曝下に，できるだけ薄く，重複したり，隣接した多数 の断層像を作成することが必要であるかいなか？医療 被曝とリスクについてわれわれ医療人は一考をようする のではないか？

装置

坐長 西尾清美（鳥取市立病院）

\section{7. 低吸収カーボンカセッテの特性について}

岡山大学医学部附属病院中央放射線部

○北山卓一・小栗宣博・稲村圭司

門久繁文・延原栄太郎・三上泰隆

菘島紀志夫

（指導 助教授 青野 要）

咋年来市販されている，軽量かつ徒来より低線量です むという炭素繊維強化樹脂製カセッテについての報告は， すでになされているが，今回てれらの利点が最大に発揮 できる撮影範囲を求めることを主眼として，その特性に ついて主としてカセッテのX線透過性の面から, 従来の カセッテと比較検討した. 前面板の吸収は，アルミ製に 比べ透過性に優れ，特に低電圧で顕著である. $60 \mathrm{kVp}$ 以下では約 $25 \%$ の被曝線量低減が可能で，幼小児撮影に おいて利用価值が高い。また, 軽量で取扱いが容易であ る. 画質について MTFでは有意差がなく，コントラス トは多少良好であった。压着不良については，彎曲の状 熊から原形に複した時の増感紙圧着不良については問題 ない.

\section{8. 圧着によるボケ像と時間的変化}

島根県立中央病院放射線科

○越間晴夫・高橋 康・安部英志 新井 但・大塚雄造

〔目的〕当院で使用の自動搬送圧着システムの生着に 起因するボケ像と濃度ムラの示現と時間的変化の検討。

〔結果〕自動搬送圧着システム 6 装置では形式，機構 の同異種に関わらずボケ像の発生部位, 広さ, 強弱等す べて異り各装置固有のあのである. 現状では自動システ ムの圧着完了のサインが良好な撮影可能状態となってい
ず，乙れは圧着後短時間（～5 秒）であ同様である.乙 の事は臨床写真では細部の識別能の低下という形で表わ れている.しかし各装置により異るが圧着後の時間経過 により確実にボケ区域の減少，ボケ部分の画質の向上を 認めた。笽重なチェックと管理の重要さを認識せねば自 動化に伴う情報量の低下という賏念む生じてくる.

\section{9. 島津製下肢血管自動連続撮影システムについて 川崎医科大学附属川!崎病院 ○松尾孝人・内藤誠治}

〔目的]当院では，下肢血管撮影においで，従来は， 長尺カセッテ，あるいは連続撮影装置 (AOT) を使用し ていたが今回，島津製下肢血管自動連続撮影システムに よる下肢血管撮影を行ったので，てのシステムの概要な らびに使用経験を報告する。

〔結果〕島津製下肢血管自動連続撮影システムは，制 御器, 検診台, 連続撮影装置, 下肢アンギオ駆動部およ び下肢アンギオコントロールを組合せたもので，一円の 造影剤注入により全下肢の連続的な血管像が，ブレもな く至適濃度で撮影できて，極めて有用であうた。

\section{0. 新・旧検診車の比較}

山口県済生会下関総合病院診療放射線

$$
\text { ○前平 晃・技師一同 }
$$

〔目的〕集団検診において，「大量迅速処理」という ことは当然であるが，検診車は，空間に限りがあり，装 置機能むなかなか思うにまかせない。

今回私たちは，新検診車購入の機に恵まれたわけだが， この点について改良を試みたので，旧検診車と比較して 報告する.

[改良点之結果]

○アンダーチューブ方式〜オーバーチューブ方式

天板〜テーブル・管球〜テーブルの距離が， $43 \mathrm{~cm} \cdot$ $85 \mathrm{~cm}$ となり, 被検者の出入り，体位変換，安全確認が 容易となり，撮影のタイミングあ取り易くなった。

○ミラ一方式（监光板式をモニター式への改良型）～I·I 方式

装作室の暗室化む不用となり，画像も見易くなった。 被曝量は，必然的に軽減した。

○天板縦移動型～管球一I.I 縦移動型

被検者の体格によっては，天板縦移動範囲に限界を生 じ，その都度しゃがんでもらっていたが，全くその必要 はなくなった。

(ㅇ)ローリングスピードを $30^{\circ} / 7 \mathrm{sec}$ 〜 $30^{\circ} / 4 \mathrm{sec}$.

$30^{\circ} / 7 \mathrm{sec}$.では，口頭指示による体位変数の方が速か ったが，30\% $4 \mathrm{sec}$.ではローリングを使用した方が速く， 